\title{
Widespread Abdominal Splenosis Diagnosed During Cesarean Section: A Case Report
}

\author{
Sezaryan Esnasında Saptanan Batın Içine Geniş Yayılımlı Abdominal \\ Splenozis Olgusu
}

\author{
๑ Tayfun Bilgiç \\ Acıbadem Kadıköy Hospital, Clinic of General Surgery, Istanbul, Turkey
}

\begin{abstract}
Splenosis is an autotransplantation of splenic tissue that usually occurs after surgery or traumatic rupture of the spleen. It is not a pathological process. In this case, the patient underwent cesarean section, and during cesarean section, there were small masses detected on the small intestines and peritoneum. Multiple biopsies were taken from the masses and histopathological analysis was compatible with abdominal splenosis.
\end{abstract}

Keywords: Splenosis, ceserean section, wide spread, intraabdominal

\begin{abstract}
Splenozis dalağın travması ya da dalak cerrahi esnasında dalak parçalarının ototransplantasyonudur. Bu durum patolojik bir süreç değildir. Bu çalışmada, sezaryen esnasında batın içinde ince barsaklar ve periton üzerinde yaygın olarak saptanan küçük kitlelerden bahsedilmektedir. Bu kitlelerden alınan biyopsi sonucu splenozis ile uyumlu bulunmuştur.
\end{abstract}

Anahtar Sözcükler: Splenozis, sezeryan, yaygın, intraabdominal

\section{Introduction}

Splenosis is often found incidentally. The first human case of splenosis was reported in 1896 by Albrecht in Germany (1) and the term splenosis was proposed by Buchbinder and Lipkopf in 1939. It describes heterotopic autotransplantation of splenic tissues (2). Splenosis mostly occurs in the abdominal and pelvic cavities, and rarely, in other locations throughout the body (3). It requires no further treatment; however, sometimes imaging findings can mimic malignancy and metastases (3). In these cases, it is important to make differential diagnosis.

Splenic implants regain their function, and the primary hematologic disease may return back. In these cases, management of the primary disease will be difficult. In the differential diagnosis of splenosis, we can count accessory spleens, endometriosis, hemangiomas and metastatic cancer (4).

In this paper, we present a case of splenosis detected during cesarean section (c/s) 20 years after traumatic rupture of the spleen in childhood, which was asymptomatic since then.

\section{Case}

A 34-year-old pregnant patient was scheduled for a cesarean section. Her medical history included splenectomy after a traffic accident. Biochemical and hematologic parameters were normal. Cesarean section was performed with a Pfannenstial incision and she delivered healthy baby weighing $3000 \mathrm{~g}$ without any anomaly. During the procedure, the surgical team saw small masses on the intestines and peritoneum and requested general surgery consultation. During surgery, it was observed that there were multiple masses measuring 1-3 cm suggesting exophytic solid vascular structures on the intestine, particularly on the serosal surface of the bowel loops and the mesenteric face, pouch of Douglas, and sigmoid colon (Figure 1a, b). The patient was discharged on the third postoperative day without
Address for Correspondence/Yazışma Adresi: Tayfun Bilgiç, Acıbadem Kadıköy Hospital, Clinic of General Surgery, İstanbul, Turkey

Phone: +90 5326557134 E-mail: tbilgic77@gmail.com ORCID: orcid.org/0000-0002-7564-3663

Received/Geliş Tarihi: 22 June 2018 Accepted/Kabul Tarihi: 22 June 2018

The article was presented as an oral presentation at the $1^{\text {st }}$ International Ahi Evran Medicine ve Health Sciences Congress.
${ }^{\circ}$ Copyright 2019 by The Medical Bulletin of istanbul Haseki Training and Research Hospital The Medical Bulletin of Haseki published by Galenos Yayınevi. 'Telif Hakkı 2019 istanbul Haseki Eğitim ve Araştırma Hastanesi Haseki Tip Bülteni, Galenos Yayınevi tarafindan yayınlanmıştır. 

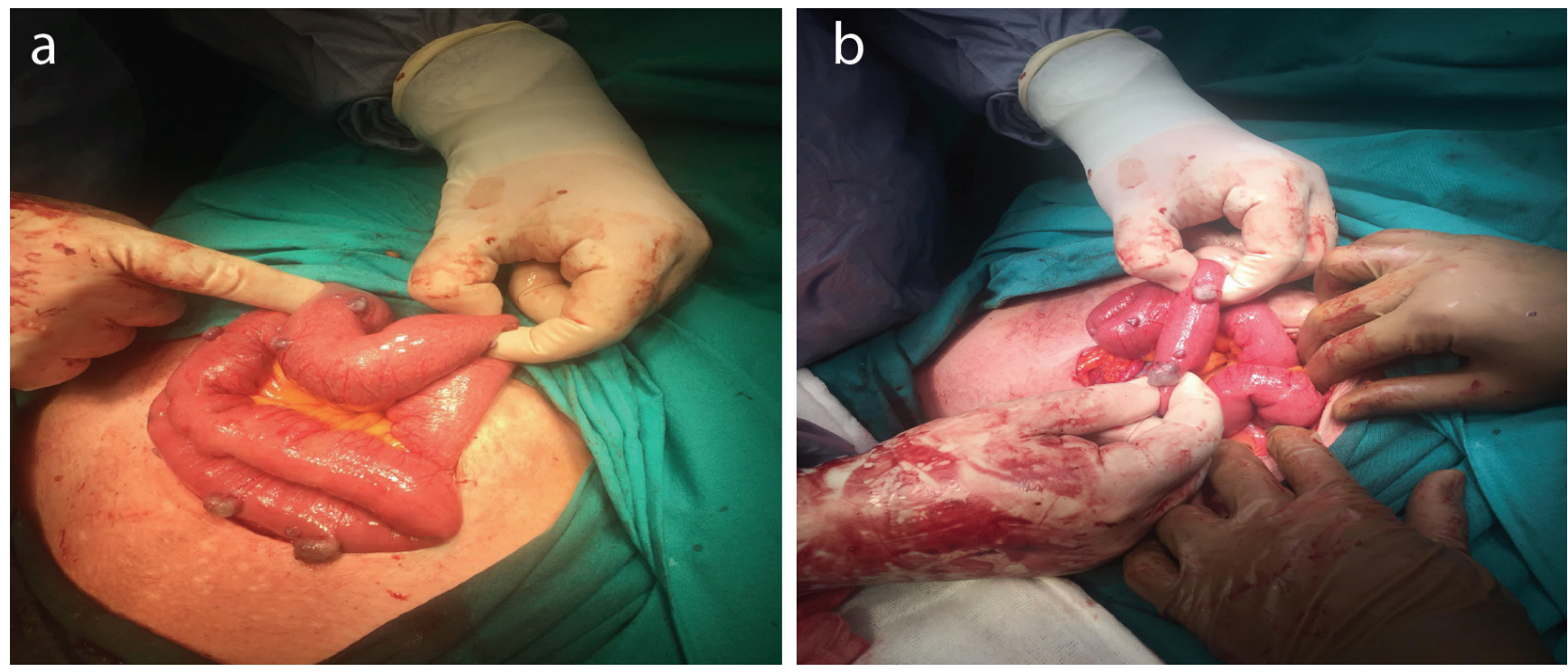

Figure 1a, b. Splenic implants on small intestines seen during surgery

any problem. Postoperative histopathological examination revealed abdominal splenosis. Written informed consent for publication of her clinical details and images was obtained from the patient.

\section{Discussion}

Splenosis is the autotransplantation of splenic parenchyma occurring during surgery or due to splenic trauma. Splenosis can be found throughout the abdominal cavity or pelvic cavity; in some cases, it can be found in the chest cavity, in subcutaneous tissues or in the brain (4). After rupture of the splenic parenchyma, the capsule compromises and splenic fragments usually spread by a direct seeding onto neighboring locations. Splenules are usually intraperitoneal. Extra-peritoneal splenosis is less common and usually related to direct communication with the peritoneum during trauma or splenectomy (5-8).

The true incidence of this rare condition, which is often under diagnosed, is unknown. The heterotopic implantation of splenic tissue may occur in up to $67 \%$ of patients with a traumatic rupture of the spleen or splenectomy. Splenosis is often detected incidentally on imaging or during surgery as in our case. It can be solitary or multiple, and it can occur in anywhere in the body, commonly in the abdominal cavity (7). In our case, multiple masses were detected in the abdominal cavity.

Splenic implants are usually asymptomatic, however, sometimes they may cause recurrent abdominal pain or small bowel obstruction. There are only case reports in the literature to show small bowel obstruction due to splenosis (9). Rarely, splenosis may present with gastrointestinal bleeding, abdominal mass or compression symptoms of a mass and may be related to recurrence of hematologic diseases treated previously with splenectomy (10). In our case, we did not detect any hematological problems or compression of any abdominal organ.

\section{Conclusion}

The risk of splenosis and associated complications shoud be kept in mind in patients with a history of a splenectomy or rupture of the spleen.

\section{Authorship Contributions}

Financial Disclosure: The author declared that this study received no financial support.

\section{References}

1. Cohen EA. Splenosis: review and report of subcutaneous splenic implant. Ama Arch Surg 1954;69:777-84.

2. Buchbinder JH, Lipkoff CJ. Splenosis: multiple peritoneal splenic implants following abdominal injury. Surgery 1939;6:927-34.

3. Lake ST, Johnson PT, Kawamoto S, et al. CT of Splenosis: patterns and pitfalls. AJR Am J Reontrgenol. 2012;199:W68693.

4. Fleming $C R$, Dickson ER, Harrison EG Jr. Splenosis: autotransplantation of splenic tissue. Am J Med 1976;61:4149.

5. Perry KT Jr, Zisman A, Singer J, et al. Splenosis presenting as a right suprarenal retroperitoneal mass. J Urol 2002;168:644-5.

6. Louie-Johnsun M, Gilbourd D. Unusual retroperitoneal splenosis confirmed by laparoscopic retroperitoneal excisional biopsy. ANZ J Surg 2012;82:758. 
7. Valli M, Arese P, Gallo G, et al. Right Retroperitoneal splenosis presenting as an adrenal mass. Eur J Surg 1999;165:1197-98.

8. Imbriaco M, Camera L, Manciuria A, et al. A case of multiple intra-abdominal splenosis with computed tomography and magnetic resonance imaging correlative findings. World J Gastroenterol 2008;14:1453-55.
9. Younan G, Wills E, Hafner G. Splenosis: A Rare Etiology for Bowel Obstruction-A Case Report and Review of the Literature. Case Rep Surg 2015;2015:890602.

10. Ksiądzyna D. A case report of Abdominal Splenosis - a Practical mini-Review for a Gastroenterologist. J Gastrointestin Liver Dis 2011;20:321-4. 